Velden, L.F.J. van der, Francke, A.L., Hingstman, L., Willems, D.L. Ontwikkelingen in de sterfte aan kanker en andere chronische aandoeningen. TSG: Tijdschrift voor

Gezondheidswetenschappen: 2008, 86(7), 399-404

\begin{tabular}{|l|l|}
\hline Postprint Version & 1.0 \\
\hline Journal website & $\underline{\text { http://vb23.bsl.nl/frontend/index.asp?_custom_product_id=1388-7491 }}$ \\
\hline Pubmed link & \\
\hline DOI &
\end{tabular}

This is a NIVEL certified Post Print, more info at http://www.nivel.eu

\title{
Ontwikkelingen in de sterfte aan kanker en andere chronische aandoeningen
}

\author{
LUD VAN DER VELDEN* ,ANNEKE FRANCKE** ,LAMMERT HINGSTMAN** ,DICK \\ WILLEMS*** \\ * senior-onderzoeker NIVEL, Utrecht \\ ** programmaleider NIVEL, Utrecht \\ *** AMC/UvA, afdeling huisartsgeneeskunde, Amsterdam \\ Dr. Lud van der Velden, NIVEL, Postbus 1568, 3500 BN Utrecht, e-mail: \\ I.vandervelden@nivel.nl
}

Inleiding: Voor de vormgeving van beleid op het gebied van palliatieve zorg is het van belang inzicht te hebben in kenmerken van mensen die overlijden aan een niet-acute aandoening. Daarom is onderzoek verricht naar het aandeel van de sterfte dat is veroorzaakt door niet-acute aandoeningen, het aandeel daarin van verschillende aandoeningen en naar waar de niet-acute sterfte plaatsvindt. Methode: Analyse van sterftecijfers van het Centraal Bureau voor de Statistiek. Resultaten: In 2006 overleden ongeveer 135.000 personen, waarvan 73.000 (54\%) aan een chronische aandoening. Kanker was veruit de meest voorkomende niet-acute doodsoorzaak (ongeveer 40.000 overledenen). CVA (na correctie voor acute sterfte), COPD, dementie en hartfalen waren ook frequente niet-acute doodsoorzaken, met elk rond de 6.000 overledenen in 2006. Bijna 90\% van de niet-acuut overledenen was van Nederlandse herkomst, 8\% was westers allochtoon en $2 \%$ was niet-westers allochtoon. Vrijwel eenderde van de mensen overleed thuis, $27 \%$ in een ziekenhuis, $25 \%$ in een verpleeghuis en $15 \%$ elders. Ten opzichte van 1996 is de sterfte aan chronische aandoeningen met $0,7 \%$ per jaar gestegen. Discussie: Een verdere groei van de niet-acute sterfte is te verwachten. Het aantal niet-westerse allochtonen dat aan een chronische aandoening zal sterven, zal gaan groeien.

\section{INLEIDING}

In 2006 overleden in Nederland ongeveer 135.000 mensen (CBS, statline). Een deel van deze mensen stierf acuut en onverwacht, terwijl een ander deel overleed aan kanker of een andere chronische aandoening. Bij deze laatste groep mensen is de dood ingetreden na een min of meer langdurig ziekbed en daarmee vormen ze de doelgroep van palliatieve zorg.

Voor het vormgeven van beleid van de palliatieve zorg is het belangrijk om inzicht te hebben in relevante achtergrondkenmerken van mensen die overlijden aan kanker of andere chronische aandoeningen. In 2000 voerde het NIVEL voor het eerst een analyse uit van nietacute sterfte. ${ }^{1,2}$ Voorspeld werd dat tussen 1997 en 2015 de niet-acute sterfte en de behoefte 
Velden, L.F.J. van der, Francke, A.L., Hingstman, L., Willems, D.L. Ontwikkelingen in de sterfte aan kanker en andere chronische aandoeningen. TSG: Tijdschrift voor

Gezondheidswetenschappen: 2008, 86(7), 399-404

aan terminale zorg met ongeveer $20 \%$ zou stijgen, dus met ruim $1 \%$ per jaar, en dat het aandeel van de mensen die thuis overlijden zou stijgen.

De hier gepresenteerde analyse van niet-acute sterfte is gefinancierd door het Ministerie van VWS en betreft een actualisering van de studie uit 2000. Actualisering was noodzakelijk omdat de vorige studie betrekking had op sterftegegevens die inmiddels tien jaar oud waren. Ook was actualisatie belangrijk omdat het huidige kabinet palliatieve zorg als een speerpunt van het overheidsbeleid heeft gekozen. ${ }^{3}$

Wij beantwoorden in dit artikel de volgende vragen.

1. Hoeveel Nederlanders overleden in 2006 ten gevolge van kanker en andere chronische aandoeningen?

2. Wat zijn hun demografische kenmerken (leeftijdscategorie, sekse en etniciteit)?

3. Met hoeveel procent is de sterfte aan kanker en andere chronische aandoeningen tussen 1996 en 2006 toegenomen?

4. Wat was de plaats van overlijden (thuis, ziekenhuis of elders) van de mensen die in 2006 zijn overleden aan een chronische aandoening en is dat de afgelopen jaren veranderd?

De uitkomsten van dit onderzoek zijn overigens meer in detail beschreven in een onderzoeksrapport. ${ }^{4}$ In dat rapport wordt ook uitgebreid ingegaan op de mate waarin de ontwikkelingen in de niet-acute sterfte in de eerste studie ${ }^{1,2}$ goed zijn voorspeld.

\section{METHODE}

Gegevens over het totaal aantal Nederlanders dat is overleden aan chronische aandoeningen over de jaren 1996 tot en met 2006, de primaire doodsoorzaak, de leeftijd en het geslacht van de overleden personen zijn verkregen van het CBS. Verder zijn van het CBS ook gegevens verkregen over de plaats van overlijden en etniciteit voor de jaren 2003 tot en met 2006. De CBS-registraties zijn overigens gebaseerd op de door de arts ingevulde overlijdensverklaring.

Wij hebben via het CBS uitsluitend gegevens geselecteerd van personen die als primaire doodsoorzaak een chronische aandoening hadden waarvan bekend is dat het overlijden daaraan vaak gepaard gaat met een ziekbed en derhalve met (een behoefte aan) palliatieve zorg (tabel 1). Een tweede selectiecriterium was dat het moest gaan om minimaal rond de 50 overledenen per jaar. Chronische aandoeningen die voor wat betreft het aantal overledenen als heel klein zijn aan te merken, zoals asbestose of cystische fibrose, zijn dus buiten beschouwing gelaten. Een praktisch punt daarbij was dat het moest gaan om aandoeningen die op het niveau van de drie cijferige ICD-10 aanduiding als 'chronisch' zijn aan te merken. Het Ministerie van VWS wilde in de analyse van de sterftegegevens ook zo veel mogelijk aandacht voor de relatie met etniciteit. Dit vanuit het feit dat vrij weinig bekend was over bijvoorbeeld de plaats van overlijden en andere relevante demografische kenmerken onderscheiden naar doodsoorzaak van allochtone Nederlanders. De gegevens over de etniciteit zijn alleen verkregen als een totaal voor de gehele periode 2003 tot en met 2006 (voorafgaand aan 2003 registreerde het CBS bij de doodsoorzaken nog niet de etniciteit). Specifiekere gegevens over etniciteit onderscheiden naar de verschillende jaren en diagnosecategorieën konden door het CBS niet geleverd worden omdat in dat geval de anonimiteit van de personen niet gegarandeerd was.

[TABEL 1]..

Voor wat betreft de sterfte aan CVA, is rekening gehouden met het feit dat mensen met CVA soms acuut en onverwachts overlijden. Op basis van bestaand onderzoek (onder andere Hartmann e.a., 2001) kan aangenomen worden dat ongeveer een derde acuut overlijdt na een CVA. Daarom is slechts 67\% van het aantal overledenen met CVA als primaire doodsoorzaak gerekend als niet-acute sterfte. 
Velden, L.F.J. van der, Francke, A.L., Hingstman, L., Willems, D.L. Ontwikkelingen in de sterfte aan kanker en andere chronische aandoeningen. TSG: Tijdschrift voor

Gezondheidswetenschappen: 2008, 86(7), 399-404

Naast gegevens over de overledenen per jaar, zijn via het CBS ook gegevens verzameld over de levende bevolking per 1 januari van de jaren 1996 tot en met 2006 naar leeftijd, geslacht en etniciteit (CBS, statline).

\section{RESUlTATEN}

\section{Aantal overledenen in 2006 per doodsoorzaak}

In 2006 zijn in Nederland zo'n 73.000 personen overleden aan één van de door ons geselecteerde chronische aandoeningen. Dat is $54 \%$ van het totale aantal van 135.000 overledenen. Bij iets meer dan 40.000 overleden personen was kanker de primaire doodsoorzaak (zie figuur 1). De sterfte aan elk van de andere chronische aandoeningen is veel minder groot. Aan CVA, dat - ondanks de 33\% aftrek voor acute sterfte - in aantal overledenen toch de tweede plaats inneemt, zijn 6.600 mensen niet-acuut overleden.

Verder is er nog een drietal chronische aandoeningen te zien waar per aandoening zo'n 6.000 mensen per jaar aan overlijden: COPD, dementie en hartfalen.

\section{[FIGURE 1]}

\section{Sterfte naar leeftijd, sekse en herkomst}

De leeftijdsverdeling van de personen die in 2006 aan een chronische aandoening zijn overleden, laat een piek zien bij de leeftijdscategorie van 80 tot 85 jaar (zie figuur 2). Bovendien is bijna driekwart (namelijk 72\%) minstens 70 jaar. De sterftekans blijkt vrijwel logaritmisch op te lopen met de leeftijd $\left(\mathrm{zie}^{4}\right)$. Voor een persoon van onder de dertig jaar is er een kans van minder dan 0,01\% dat deze binnen een jaar aan een chronische aandoening zal overlijden, voor een 45 -jarige is het ongeveer $0,1 \%$, voor een 70 -jarige ongeveer $1 \%$ en voor een 90 -jarige $10 \%$.

De leeftijdsverdeling van de overledenen verschilt overigens enigszins per chronische aandoening. Voor bijvoorbeeld de aan kanker overleden personen ligt de piek in de verdeling bij 75-80 jaar. Voor CVA, COPD, diabetes, Parkinson en nierziekten ligt de piek bij 80-85 jaar en voor dementie en hartfalen bij 85-90 jaar.

\section{[FIGUUR 2]}

Van alle personen die in 2006 overleden aan een chronische aandoening, was 51\% vrouw $\left(z^{4}{ }^{4}\right)$. Het aandeel vrouwen blijkt te variëren met de leeftijd: in de iets oudere groepen (van 30 tot 50 jaar) is het aandeel vrouwen steeds rond de $55 \%$. Vanaf 50 jaar daalt het aandeel vrouwen naar 40\% voor de groep van 65-70 en van 70-75 jaar, om vervolgens op te lopen tot $81 \%$ bij de alleroudste leeftijdsgroep. De sterftekans voor chronische aandoeningen blijkt voor de gehele groep mannen iets lager te zijn dan voor vrouwen: $0,44 \%$ tegenover $0,45 \%$. Maar in de oudere leeftijdsgroepen hebben mannen een duidelijk grotere kans om aan chronische aandoening te sterven dan vrouwen. In de leeftijd van bijvoorbeeld 80-85 jaar hebben mannen een kans van 5,2\% om binnen één jaar aan een chronische aandoening te sterven, terwijl vrouwen in de leeftijdsgroep een kans van 3,1\% hebben.

Van allen die overleden aan een chronische aandoening in de periode vanaf 2003 tot en met 2006, was nog geen $2 \%$ van niet-westerse herkomst (zie ${ }^{4}$ ).

\section{Ontwikkelingen in niet-acute sterfte tussen 1996 en 2006 per doodsoorzaak}

De niet-acute sterfte is tussen 1996 en 2006 met 7\% toegenomen (zie figuur 3): van circa 68.400 naar 73.000 . Voor kanker blijkt het $6 \%$ te zijn geweest, met 38.200 overledenen in 1996 en 40.400 in 2006. CVA laat daarentegen een daling met 19\% zien: van 8.200 naar 6.600. Dementie heeft van alle diagnosecategorieën de grootste toename van sterfte: $72 \%$. Het gaat dan om circa 3.800 overledenen in 1996 en 6.500 in 2006. De sterfte aan COPD is met $3 \%$ gedaald (van 6.500 naar 6.300). Vervolgens is er een tweetal diagnosecategorieën te zien met rond de $12 \%$ groei van sterfte: hartfalen (van 5.300 naar 6.000) en diabetes (van 
Velden, L.F.J. van der, Francke, A.L., Hingstman, L., Willems, D.L. Ontwikkelingen in de sterfte aan kanker en andere chronische aandoeningen. TSG: Tijdschrift voor

Gezondheidswetenschappen: 2008, 86(7), 399-404

3.100 naar 3.500). De overige chronische aandoeningen waren samen verantwoordelijk voor 3.300 overledenen in 1996 en 3.600 overledenen in 2006. Voor de ziekte van Parkinson en chronische nierziekten was er een stijging met ongeveer 30\%. Voor chronische leverziekten was er een stijging van $8 \%$. Voor spinale spieratrofie is een stijging van $20 \%$ vastgesteld. De sterfte aan MS is met 19\% afgenomen. Voor AIDS is er een sterke daling geweest in de sterfte, namelijk een afname met $85 \%$.

\section{[FIGUUR 3].}

De sterftecijfers per doodsoorzaak zijn ook per jaar geanalyseerd voor de gehele periode vanaf 1996 tot en met 2006. ${ }^{4}$ Voor het totaal van de sterfte aan chronische aandoeningen is daarbij te zien dat er vooral tussen 1996 en 2002 een toename is geweest. Daarna lijkt de omvang van de niet-acute sterfte te zijn gestabiliseerd. Per specifieke aandoening zijn echter verschillende trends en/of trendbreuken te zien. Voor bijvoorbeeld kanker is de sterfte elk jaar vrijwel over de gehele periode licht gestegen. Voor bijvoorbeeld CVA is de sterfte daarentegen eerst stabiel geweest in de periode vanaf 1996 tot en met 2002, maar daarna gedaald.

\section{Plaats van overlijden in 2006 naar leeftijd, geslacht en etniciteit}

Ongeveer 27\% van de sterfte aan kanker en andere chronische aandoeningen vond in 2006 plaats in een ziekenhuis, $25 \%$ in een verpleeghuis en $10 \%$ in een verzorgingshuis (zie figuur 4). Het aandeel overledenen dat thuis is gestorven, bedroeg $32 \%$. Van $5 \%$ is de plaats van overlijden een andere dan de hierboven genoemde of was de plaats van overlijden onbekend. Bij deze 'overig en onbekend'-categorie zitten waarschijnlijk ook de mensen die zijn overleden in zelfstandige hospices of bijna-thuis-huizen. ${ }^{4}$

Van de aan een chronische aandoening overleden mannen, is het aandeel dat in een ziekenhuis overleed wat groter dan voor de vrouwen (31\% versus $24 \%$; zie figuur 4 ). Het aandeel aan een chronische aandoening overleden mannen dat in een verpleeghuis of verzorgingshuis is gestorven, is met respectievelijk $19 \%$ en $7 \%$ daarentegen juist beduidend kleiner dan bij de vrouwen (30\% respectievelijk 14\%). Van de mannen is 38\% thuis gestorven en van de vrouwen $27 \%$. Dit verschil tussen mannen en vrouwen in de plaats van overlijden hangt deels samen met een verschil in de leeftijd waarop mannen en vrouwen sterven. Maar ook binnen elk van de oudere leeftijdsgroepen zijn er aanzienlijke verschillen in plaats van overlijden tussen mannen en vrouwen. ${ }^{4}$

\section{[FIGUUR 4]}

De kans thuis te overlijden is het grootst als men nog niet hoogbejaard is: van de niet-acuut overleden personen tot 70 jaar is zelfs ongeveer $50 \%$ thuis gestorven. ${ }^{4}$ Voor de niet-acuut overledenen vanaf 70 jaar geldt dat het aandeel dat thuis sterft afneemt met de leeftijd en dat, bij eenzelfde leeftijd, vrouwen minder vaak thuis sterven dan mannen.

Er is weinig verschil tussen de autochtone Nederlanders en de westerse allochtonen voor wat betreft de plaats van overlijden (zie figuur 5). Er zijn echter wel duidelijke verschillen tussen autochtone Nederlanders en niet-westerse allochtonen qua plaats van overlijden. Voor de niet-westerse bevolkingsgroep is het aandeel dat in een ziekenhuis is overleden als gevolg van één van de onderscheiden chronische aandoeningen relatief groot ( $46 \%$ versus $28 \%$ voor de autochtone Nederlanders). Het aandeel niet-westerse allochtonen dat in een verpleeghuis overleed is relatief laag: in de onderzochte periode (2003 tot en met 2006) stierf 15\% van de aan kanker of een andere chronische aandoening gestorven niet-westerse allochtonen in een verpleeghuis, tegenover $24 \%$ bij de autochtone Nederlanders. Het aandeel overledenen in een verzorgingshuis is bij de niet-westerse allochtonen nog lager: nog geen $3 \%$ tegenover $11 \%$ bij de autochtone Nederlanders. Het aandeel bij de niet-westerse allochtonen dat thuis is overleden (31\%), is wel weer vergelijkbaar met dat van de autochtone Nederlanders (32\%). 
Velden, L.F.J. van der, Francke, A.L., Hingstman, L., Willems, D.L. Ontwikkelingen in de sterfte aan kanker en andere chronische aandoeningen. TSG: Tijdschrift voor

Gezondheidswetenschappen: 2008, 86(7), 399-404

\section{[FIGUUR 5].}

\section{Ontwikkelingen in de plaats van overlijden}

Zoals gezegd, heeft het CBS pas vanaf 2003 gegevens over de plaats van overlijden onderscheiden naar primaire doodsoorzaak. De ontwikkeling in de plaats van overlijden voor de niet-acute sterfte kon daarom alleen over de periode 2003 tot en met 2006 worden geanalyseerd. Het aandeel dat in een ziekenhuis stierf als gevolg van één van de onderscheiden chronische aandoeningen, lijkt iets te zijn afgenomen in die periode, aangezien het in 2003 nog 30\% was en in $200627 \% .{ }^{4}$ Het aandeel dat in een verpleeghuis is overleden, is tegelijkertijd een klein beetje opgelopen, van 23\% naar 25\%. Voor de verzorgingshuizen is het aandeel vrijwel stabiel gebleven. Dat is ook het geval voor het aandeel dat thuis is overleden.

\section{DISCUSSIE}

In 2006 overleden in Nederland in totaal 73.000 mensen als gevolg van kanker of één van de andere geselecteerde chronische aandoeningen (CVA, dementie, COPD, hartfalen, diabetes, de ziekte van Parkinson, chronische nierziekten, chronische leverziekten, spinale spieratrofie, MS, overige aandoeningen van het centraal zenuwstelsel en AIDS). Kanker was verantwoordelijk voor ruim de helft van deze niet-acute overlijdens.

De totale sterfte aan kanker en andere chronische aandoeningen is verantwoordelijk voor iets meer dan de helft van de gehele sterfte in Nederland, die ongeveer 135.000 overledenen bedroeg in 2006. Daarbij kan er sprake zijn van een lichte onderschatting omdat kleinere diagnosegroepen (met enkele tientallen of nog minder gevallen van overlijden per jaar) niet in onze analyses zijn meegenomen.

In de studie van Van der Heide e.a. ${ }^{6}$ komen de auteurs overigens uit op een veel hoger percentage van niet-acute sterfte: deze auteurs constateren op basis van ondervraging van artsen dat bij ongeveer $70 \%$ van de in 2001/2002 overleden Nederlanders sprake was van een niet-acuut overlijden. De discrepantie tussen de uitkomsten van Van der Heide e.a. en onze analyses zullen samenhangen met verschillen in de onderzoekssystematiek: wij baseren ons op CBS-registraties (die gebaseerd zijn op door artsen ingevulde overlijdensverklaringen) en Van der Heide e.a. baseren zich op wat artsen in vragenlijstonderzoek aangeven als niet-acuut overlijden. Vooral bij zeer oude mensen waarbij de conditie steeds slechter wordt, is de dood vrijwel nooit geheel onverwacht en acuut, ook al zal men uiteindelijk niet overlijden aan één van de door ons onderscheiden chronische aandoeningen. Dit geeft aan dat bij de interpretatie van (soms uiteenlopende) percentages over niet-acute sterfte, rekening moet worden gehouden met hoe niet-acute sterfte is geoperationaliseerd en gemeten. In hoeverre (zeer) oude mensen die niet lijden aan een specifieke terminale chronische aandoening maar als het ware aan "ouderdom" overlijden ook een doelgroep vormen die beroep doet op palliatieve zorg (met pijn- en symptoomverlichting en psychosociale en geestelijke begeleiding als centrale elementen) is een relevante vraag voor vervolgonderzoek.

Bijna driekwart van de personen die in 2006 aan een chronische aandoening zijn overleden, was minstens 70 jaar. De sterftekans blijkt daarbij vrijwel logaritmisch op te lopen met de leeftijd. Door deze samenhang van de sterftekans voor chronische aandoeningen met de leeftijd en het feit dat de bevolking in de komende jaren gaat vergrijzen, is een groei van de niet-acute sterfte te verwachten.

Van alle personen die in 2006 overleden aan een chronische aandoening, was 51\% vrouw. De sterftekans is daarbij voor de gehele groep mannen iets lager dan voor vrouwen, maar in de oudere leeftijdsgroepen hebben juist de mannen een grotere kans om aan een chronische aandoening te sterven. Dat de sterftekans voor de gehele groep mannen toch iets lager is dan voor de vrouwen, komt door het feit dat de leeftijdsopbouw van de mannen en vrouwen verschilt. Van de mannen is $8 \% 70$ jaar of ouder terwijl dit bij de vrouwen $12 \%$ is. 
Velden, L.F.J. van der, Francke, A.L., Hingstman, L., Willems, D.L. Ontwikkelingen in de sterfte aan kanker en andere chronische aandoeningen. TSG: Tijdschrift voor

Gezondheidswetenschappen: 2008, 86(7), 399-404

Van allen die overleden aan een chronische aandoening in de periode vanaf 2003 tot en met 2006, was nog geen $2 \%$ van niet-westerse herkomst. Dat is veel kleiner dan hun aandeel in de bevolking (10,5\%). In de jongste leeftijdscategorieën was het aandeel van de nietwesterse bevolking in de totale sterfte aan chronische ziekten echter zo'n 17\%. Dit is vergelijkbaar met hun aandeel in de bevolking in die leeftijdgroepen (16\%). Dat het aandeel in de totale niet-acute sterfte van de niet-westerse allochtonen kleiner is dan hun aandeel in de totale bevolking komt dus vooral vanwege het verschil in leeftijdsverdeling in vergelijking met de autochtone Nederlanders. Van de autochtone Nederlanders is 36\% 50 jaar of ouder, terwijl dit bij de niet-westerse allochtonen slechts $12 \%$ is. Met het ouder worden van de niet-westerse allochtonen, zal ook het aantal gaan groeien dat aan een chronische aandoening zal sterven.

Uit onze analyses blijkt dat tussen 1996 en 2006 de niet-acute sterfte met bijna 7\% is toegenomen. Dat is iets minder dan de in een eerdere studie uitgesproken verwachting dat er een toename zou komen van $1 \%$ per jaar in de periode $1997-2015 .{ }^{1}$ De toename van bijna $0,7 \%$ in plaats van de verwachte $1 \%$ per jaar, is enerzijds het resultaat van een opvallend lager aantal overledenen in totaal (dus inclusief de acute sterfte) ten opzichte van de sterfteprognose van het CBS waar wij ons in de vorige studie op baseerden. ${ }^{7,8}$ Anderzijds is er sprake van een opvallende en niet verwachte stijging van het aandeel sterfte aan chronische aandoeningen ten opzichte van de totale sterfte. De beperktere toename van de niet-acute sterfte is dan het resultaat van vooral een wat geringere sterfte aan chronische aandoeningen bij mannen. Deze geringere sterfte aan chronische aandoeningen zoals kanker zal voor een deel te verklaren zijn door afnemend rookgedrag van mannen enkele decennia geleden. ${ }^{9}$

In de vorige studie werd ook gesteld dat als de zorgbehoeften van de doelgroep terminale patiënten in de toekomst niet zouden wijzigen, dat dit zou betekenen dat de vraag naar palliatieve zorg ook met ongeveer 1\% per jaar toeneemt (in totaal 20\% tussen 1997-2015). Deze prognose moet nu iets naar beneden bijgesteld worden, omdat de niet-acute sterfte ook wat minder snel is toegenomen dan was verwacht. Beleidsmakers die zich bezig houden met de capaciteitsplanning voor palliatieve zorg moeten ons inziens echter rekening houden met het feit dat de omvang van de zorgvraag uiteraard niet alleen afhankelijk is van de groei van niet-acute sterfte. Door toename van mondigheid van patiënten en door uitbreiding van het aanbod aan palliatieve zorg (bijvoorbeeld op het gebied van geavanceerde pijn- en symptoombestrijding) zouden zorgbehoeften en daarmee de omvang van de zorgvraag naar palliatieve zorg ook beïnvloed kunnen worden.

In dit artikel is ook aandacht besteed aan de plaats van sterven. Daarbij is gebleken dat er een samenhang is met zowel leeftijd als geslacht. Voor wat betreft geslacht geldt dat mannen vaker thuis of in een ziekenhuis sterven dan vrouwen, ook bij een gelijke leeftijd bij sterven. Dit verschil kan wel eens van doen hebben met zowel het hebben van een partner als de leeftijd van de partner. Oudere mannen hebben vaak nog een iets jongere vrouw, waardoor mantelzorg gemakkelijker beschikbaar is. Oudere vrouwen sterven daarentegen vaker in een verpleeg- of verzorgingshuis omdat hun man inmiddels overleden is.

Inzicht in de plaats van sterven is onder meer belangrijk omdat deze meer en meer als een belangrijke kwaliteitsindicator voor goede palliatieve zorg wordt gezien. ${ }^{10}$ Uit het onderzoek van Van den Akker e.a. ${ }^{11}$ blijkt dat $73 \%$ van de algemene Nederlandse bevolking vindt dat thuis de meest ideale plaats is om te sterven voor mensen die ongeneeslijk ziek zijn. In dit licht is het opmerkelijk dat maar een derde van de mensen die aan kanker of andere chronische aandoeningen is overleden, in de eigen woning sterft en ongeveer een kwart in het ziekenhuis. Mensen die overlijden in een verzorgingshuis of een verpleeghuis verblijven daar veelal al langere tijd, echter sterven in een ziekenhuis impliceert dat er hoogstwaarschijnlijk in de palliatieve, terminale fase nog transities in de zorg hebben plaatsgevonden. Dergelijke transities brengen vaak onrust en ongemak voor patiënt en familie met zich mee en dienen daarom waar mogelijk te worden voorkomen. ${ }^{1}$ 
Velden, L.F.J. van der, Francke, A.L., Hingstman, L., Willems, D.L. Ontwikkelingen in de sterfte aan kanker en andere chronische aandoeningen. TSG: Tijdschrift voor

Gezondheidswetenschappen: 2008, 86(7), 399-404

Tot slot nog een opmerking over de validiteit en bruikbaarheid van de gebruikte overlijdensgegevens van het CBS. Een praktisch voordeel was dat het een landelijke, bestaande gegevensset betreft die zonder grote kosten door het CBS ter beschikking werd gesteld. Omdat deze CBS-gegevens grotendeels gebaseerd zijn op overlijdensverklaringen van de behandelend arts (die de patiënt veelal goed kent) kan er vanuit worden gegaan dat de gegevens over de primaire doodsoorzaak in principe zorgvuldig zijn ingevuld en valide zijn. Bovendien creëert het gebruik van dergelijke gegevens ook een mogelijkheid om om de zoveel jaar te kijken in hoeverre trends in sterfte en daarmee samenhangende demografische kenmerken zich ontwikkelen.

\section{DEVELOPMENTS IN THE MORTALITY CAUSED BY CANCER AND OTHER CHRONIC DISEASES}

Background: For palliative care, it is relevant to have insight into non-acute mortality. A study is performed to gain insight into the proportion of deaths caused by chronic diseases, the share of specific diseases within the non-acute deaths and the place of death. Methods: Analysis of death statistics of CBS (Statistics Netherlands). Results: In 2006, 135,000 people died of which 73,000 (or 54\%) died from a chronic disease. Cancer was the most frequent diagnosis (40,000 deaths). Stroke (after correction for acute deaths), COPD, dementia and hart failure were each responsible for about 6,000 deaths in 2006. Nearly $90 \%$ of the people who died were of Dutch origin, $8 \%$ were western immigrants and $2 \%$ were non-western immigrants. About one-third of the people died at home, $27 \%$ in a hospital, $25 \%$ in a nursing home and $15 \%$ somewhere else. Compared to 1996, death caused by chronic diseases has risen by around $0,7 \%$ every year. Conclusion: We expect a further increase of the total number of non-acute deaths in the Netherlands. The number of non-western immigrants dying caused by a chronic disease is expected to increase.

Dit onderzoek is gefinancierd door het Ministerie van VWS.

\section{LITERATUUR}

1. Francke AL, Willems DL. Palliatieve zorg vandaag en morgen. Feiten, opvattingen en scenario's. Maarssen: Elsevier gezondheidszorg, 2000.

Velden LFJ van der, Francke AL, Willems DL, Stokx LJ, Hingstmam L. Sterfte aan niet-

2. acute aandoeningen; enkele prognoses en de mogelijke gevolgen voor de zorgvraag. Tijdschr Gezondheidswet 2003;81:85-90.

3. Bussemaker J. Palliatieve zorg: de pioniersfase voorbij. Brief aan de Voorzitter van de Tweede Kamer der Staten-Generaal. Den Haag: Ministerie van VWS, 2007.

Velden LFJ van der, Francke AL, Hingstman L, Willems DL. Sterfte aan kanker en

4. andere chronische aandoeningen. Kenmerken in 2006 en trends vanaf 1996. Utrecht: Nivel, 2007.

5. Hartmann A, Rundek $\mathrm{T}$, Mast $\mathrm{H}$ et al. Mortality and causes of death after first ischemic stroke. Neurology 2001;57:2000-5.

6. Heide $A$ van der, Deliens L, Faisst $\mathrm{K}$ et al. End-of-life decision-making in six European countries: descriptive study. Lancet 31;2003:345-50.

7. CBS. Bevolkingsprognose 1998-2050. CBS, Maandstatistiek van de Bevolking. januari 1999: 66-75.

8. CBS/VWS. Vademecum gezondheidstatistiek. Heerlen/Den Haag: CBS/VWS, 1999.

9. Jong A de, Meulen A van der. Prognose van sterfte naar doodsoorzaken: model en 
Velden, L.F.J. van der, Francke, A.L., Hingstman, L., Willems, D.L. Ontwikkelingen in de sterfte aan kanker en andere chronische aandoeningen. TSG: Tijdschrift voor

Gezondheidswetenschappen: 2008, 86(7), 399-404

veronderstellingen. CBS, Bevolkingstrends 2005; 53(2):50-62.

10. Cohen J. End-of-life decision and place of death in Belgium and Europe. (Dissertatie) Brussel: vrije Universiteit Brussel, 2007.

11. Akker $\mathrm{P}$ van den, Luikx $\mathrm{K}$, Wersch $\mathrm{S}$ van. Waar wilt $\mathrm{u}$ doodgaan? Keuzen en overwegingen. Tilburg: IVA / VPTZ, 2005.

\section{TABELEN EN FIGUREN}

Tabel 1. Geselecteerde primaire doodsoorzaken

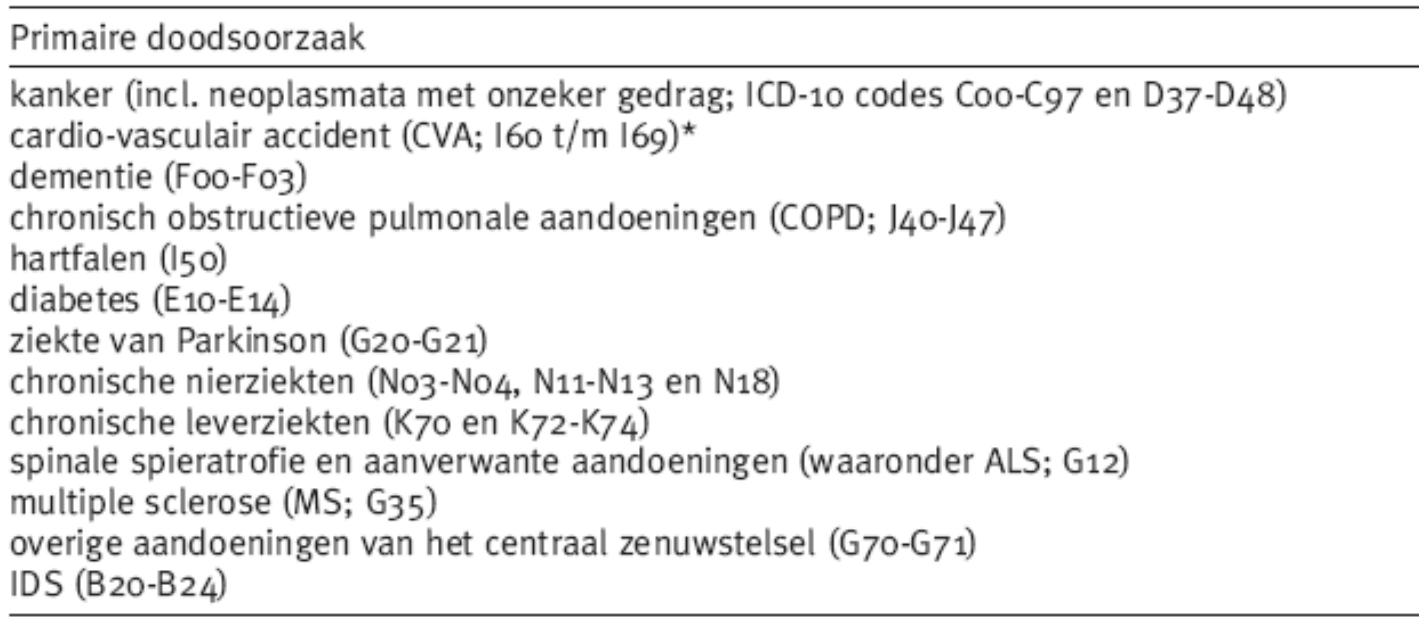

* gecorrigeerd voor $33 \%$ acute sterfte (o.a. Hartmann e.a. ${ }^{5}$ )

Figuur 1.. Aantal overledenen aan chronische aandoeningen in 2006 naar primaire doodsoorzaak

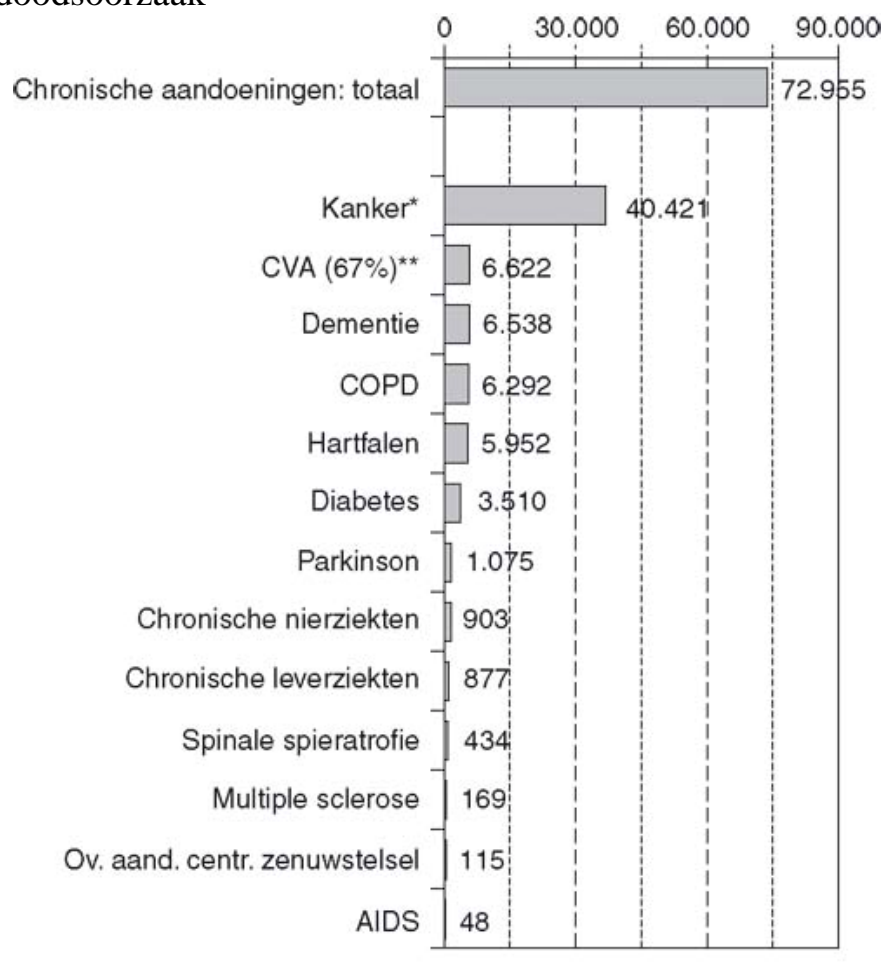

Aantal overledenen aan een chronische aandoening 2006 
Velden, L.F.J. van der, Francke, A.L., Hingstman, L., Willems, D.L. Ontwikkelingen in de sterfte aan kanker en andere chronische aandoeningen. TSG: Tijdschrift voor

Gezondheidswetenschappen: 2008, 86(7), 399-404

Figuur 2. Aantal overledenen aan chronische aandoeningen in 2006 naar leeftijd

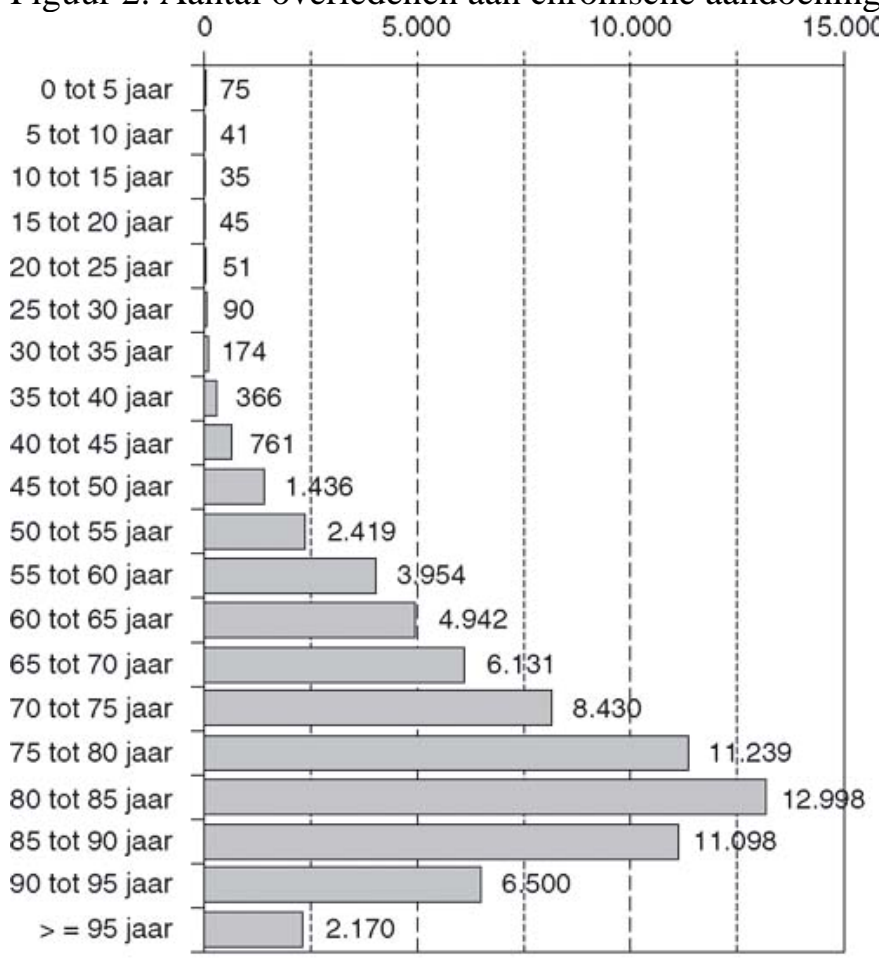

Aantal overledenen aan een chronische aandoening 2006

Figuur 3.. Percentage verandering in sterfte aan chronische aandoeningen vanaf 1996 tot aan 2006 naar primaire doodsoorzaak

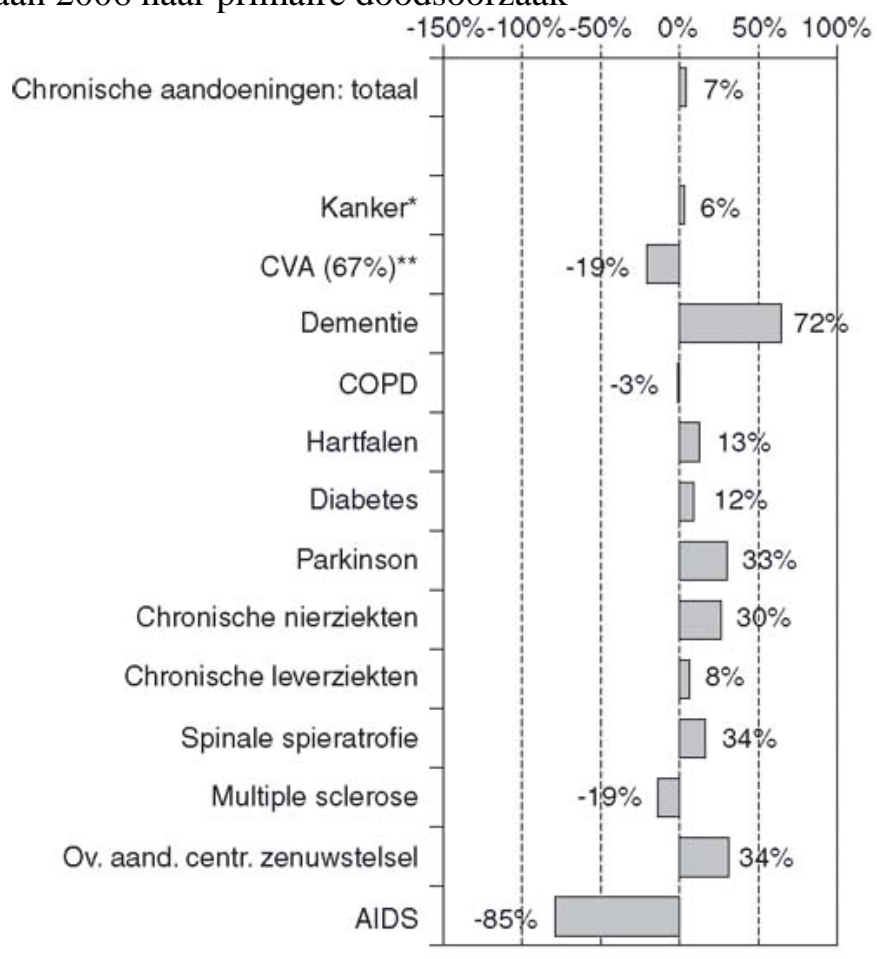

$\%$ verandering in sterfte aan chronische aandoeningen 1966-2006 
Velden, L.F.J. van der, Francke, A.L., Hingstman, L., Willems, D.L. Ontwikkelingen in de sterfte aan kanker en andere chronische aandoeningen. TSG: Tijdschrift voor

Gezondheidswetenschappen: 2008, 86(7), 399-404

Figuur 4.. Plaats van overlijden naar geslacht, voor overledenen aan chronische aandoeningen in 2006

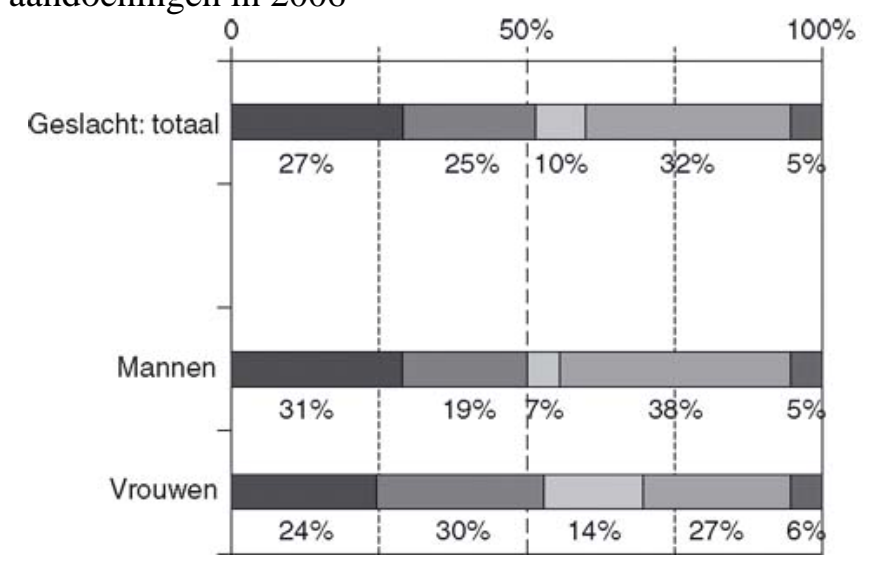

Figuur 5.. Plaats van overlijden naar herkomst, voor overledenen aan chronische aandoeningen in 2003 tot en met 2006

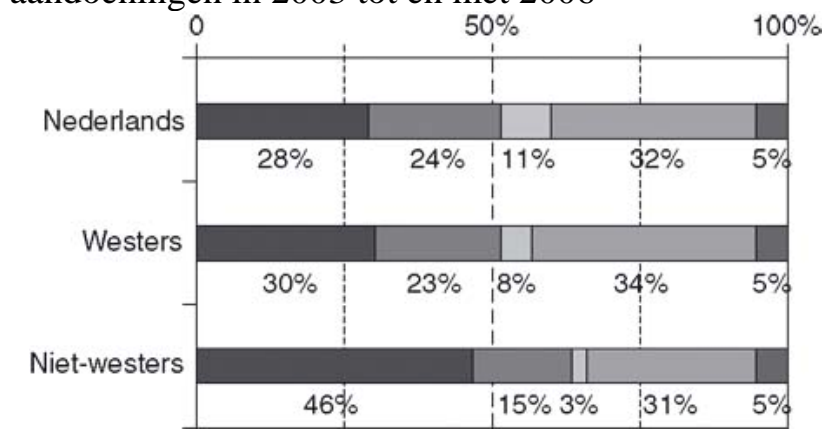

